\title{
Jesuit Foreign Missions. A Historiographical Essay
}

\author{
Ronnie Po-chia Hsia \\ Edwin Erle Sparks Professor of History, The Pennsylvania State University, \\ Department of History, University Park, PA 16802, USA \\ rxh46@psu.edu
}

\begin{abstract}
A review of recent scholarship on early modern Jesuit missions, this essay offers a reflection on the achievements and desiderata in current trends of research. The books discussed include studies on Jesuit missions in China (Matteo Ricci), on the finances of the eighteenth-century Madurai mission in India, the debates over indigenous missions in the Peruvian province in the sixteenth and early seventeenth century, on print and book culture in the Jesuits' European missions, and finally a series of studies on German-speaking Jesuit missionaries in Brazil, Chile, and New Granada.
\end{abstract}

\section{Keywords}

Jesuit - mission - conversion - historiography - China - Peru - printing - India Brazil - Chile - New Granada - Matteo Ricci

The contradictions were there from the beginning. After Ignatius's conversion in Manresa, the future founder of the Society of Jesus wanted to travel and evangelize but was frustrated in his attempt to work in the Holy Land. Instead, he chose the path of studies and became the founder of a new order, the most important community in the Catholic world facing the Protestant challenge, much maligned, lavishly praised, and immensely successful in revitalizing the fortunes of the Roman church. As a sometime pilgrim and missionary, Ignatius bore his own cross of immobility and daily administration in Rome as the founding superior general. In contrast, one of his first companions, Francis Xavier, had departed Europe for Asia and won reputation (and sainthood) as the first Jesuit missionary, whose example would inspire many future generations. The impulse to embark on missions, however, was restrained by the 
unexpected and unsolicited success in Europe, as the fathers of the Society were called to establish colleges and teach Christian doctrine to the sons of Catholic elites and Protestant "heretics," and to bring the culture of Renaissance humanism to the Europe of Catholic renewal. How well this educational enterprise succeeded exceeded anyone's first expectations. In time, the Jesuit colleges would absorb the bulk of manpower within the Society. The Collegio Romano, founded in 1551, was one of the first of the many colleges, numbering 372 in 1612 and still increasing, located on four continents. Yet, the impulse for mobility and missions never waned.

\section{Iberian Colonialism and Jesuit Missions}

The first generations of Jesuit missionaries sailed on Portuguese ships. Finding royal support in the person of João III (1521-1557), the Society established a strong presence in Portugal and her overseas colonies in Africa and Asia. In 1549, half a century after Vasco da Gama's voyage to India, there were forty-five Jesuit missionaries in Portugal's overseas dominions. This was the year when Xavier arrived in Japan and the first Portuguese Jesuits sailed to Brazil. By 1571, the number rose to 210 ; and in 1607 , only sixty some years after the foundation of the Society, there were 559 Jesuits in Portuguese Africa and Asia. ${ }^{1}$ While the majority of the missionaries were Portuguese, a significant number of Italians and Belgians joined their ranks. The Jesuit colleges, residences, and missions under the padroado, the royal Portuguese patronage in Africa and Asia, would constitute an increasingly important part of the Jesuit enterprise. These were found all along Portuguese navigation routes: in Angola, Mozambique, Bassein, Goa, Cochin, Sri Lanka, Malacca, Macao, and Nagasaki, among other places. By the 1580s, under Portuguese patronage, Jesuit missionaries had settled in India, China, and Japan and Spanish Jesuits had arrived in the Philippines from Acapulco in Mexico.

Habsburg Spain was the other great patron of Jesuit missions. In the first decades, the Society encountered more difficulties in the homeland of its founder than in Portugal, due to the hostility of established religious orders (particularly the Dominicans), suspicions of its relatively open policy toward admitting conversos, and the tensions between the Spanish province and Rome. Jesuit missionaries arrived in Spanish America much later than the mendicant friars: in Florida in 1566, Peru in 1568, and Mexico in 1570. But under

1 Dauril Alden, The Making of an Enterprise. The Society of Jesus in Portugal, Its Empire, and Beyond, 1540-1750 (Stanford: Stanford University Press, 1996), 46. 
the leadership of José de Acosta, the first provincial in Peru, the Society rapidly caught up in the missionary field and became the most dynamic force in the expansion of Christian and Spanish colonial frontiers.

The Jesuit enterprise had become global. It was reported and celebrated in the Litterae Annuae, private missionary letters, and singular narratives sent back and selectively published in Catholic Europe, and eagerly read across the confessional divide by Protestants and Catholics alike. Of the many publications, there were three major series: the Latin Litterae Annuae Societatis Iesu collated and published in Rome between 1581 and 1654, which comprised reports from all Jesuit institutions, including many missionary reports; the well-known Lettres édifiantes et curieuses des missions étrangères par quelques missionnaires de la Compagnie de Jésus, compiled and published in Paris between 1702 and 1776, devoted mostly but not exclusively to the work of French Jesuit missionaries; and the Neue Welt Botte, the German-language counterpart to the Lettres édifiantes, published between 1726 and 1758, consisting of translations from the Lettres édifiantes and original letters written by central-European Jesuit missionaries from Asia and the Americas. The scholarship on Jesuit missions has drawn heavily on these sources.

But the mission literature was much more of a motley collection than these three series, as Susanne Lang's study of the illustrations to Jesuit mission literature shows. A museum curator, Lang is interested primarily in book illustrations, a genre neglected by art historians. She bases her richly illustrated study on thirty-eight missionary reports found in two collections: the University Library of Mannheim and the former library of Prince Oettingen-Wallerstein from the University Library of Augsburg. Lang gives a detailed catalogue of the fifty-five editions of the thirty-eight titles and their translations and variant editions. The fifty-five editions are divided between twenty-three titles from the seventeenth century, with Ricci's De expeditione Christiana apud Sinas being the earliest book (1615), and thirty-two from the eighteenth century, with von Murr's famous collection dating from after the suppression of the Society (1785). In terms of language, French titles prevailed with twenty-two, followed by German with fifteen, Latin with fourteen, Italian with three, and Spanish with just one title. All the Latin works were published in the seventeenth century, whereas French and German (many were translations) dominated eighteenth-century publications. Many famous titles are represented-the Lettres édifiantes and Der Neue Welt-Bott; several are authored by famous missionaries (Ricci, Trigault, Martini, Mailla, Le Comte, Verbiest, and Tachard, all except the last being missionaries in China).

Despite Lang's careful cataloguing, there is an unavoidable problem of how representative her sources are, which affects the methodology and 
interpretation of Bilder zur Mission. First, many of the authors and compilers were not missionaries, and a few of them not even Jesuits. Second, the predominance of eighteenth-century French and German titles in her database reflected the history of book collection and reception in two localities of the Holy Roman Empire, not the history of Jesuit missionary publications. Above all, the paucity of Spanish-language works (only one) and the complete absence of Portuguese-language books, except in translation, tell us less about Jesuit missions than about the book market and collection practices in northern Europe, where Latin and Spanish language works, still strong at the Frankfurt Book Fair until the mid-seventeenth century, gradually vanished in the course of the eighteenth.

The haphazard nature of her choice of sources forces Lang into the only possible methodological approach-formalistic analysis-since an exhaustive archival research into book production, distribution, and reception is clearly impractical, as she rightly asserts. Hence, the chapters deal with themes that the books themselves represent: producer, artist, censor, text, paratext, layout, frontispiece, dedications, maps, plans, portraits, icons, scenes, the representation of space, the interplay between text and illustrations, the representations of nature, martyrdom, non-Europeans and non-Christian religions, etc. This makes for tedious reading. Lang belabors simple points, repeats her arguments, and states the obvious. There are also mistakes in her reading. The figures illustrating the province of Sichuan in Martini's China-Atlas (1663) are not "Seegötter" [sea gods], but the famous General Guan Yu and his attendant from the period of the Three Kingdoms (220-28o C.E.). This famous defender of the Shu Kingdom based on the province of Sichuan (115 and 119), hence the choice of the figure, is unmistakable in his iconic headgear and weapon. On page 118, the text discusses illustration 56 as the province of Guangdong, but it is in fact the province of Guizhou. The problem of source representativeness is evident on page 266, where Lang analyzes the portrait of Confucius from $\mathrm{Du}$ Halde's Description de la Chine. This famous portrait of Confucius, the first in Europe, was first printed in 1687 by the Belgian Jesuit Philippe Couplet when he visited Paris as procurator of the vice-province of China. The relevant question to ask here, as in many other missionary publications, should be about how material, as illustrations (and sometimes facts), were copied, circulated, and reprinted in different editions between the late sixteenth and eighteenth centuries. Lang also contradicts herself, as she claims in her text that no individual Chinese was painted in Europe before the end of the eighteenth century (332), whereas in her footnotes she mentions the portrait of the Chinese Jesuit Michael Shen, painted by Gottfried Kneller, the court painter of Charles II of England. It is a pity that this beautifully and carefully produced book offers 
little interpretation beyond formal analysis that is of value to the historian of the Jesuit mission, despite its wealth of reproduced illustrations.

The importance of a central guiding question, instead of sourcedriven investigation, is amply reflected in the excellent study of missions in the Jesuit province of Peru between the 1570s and 1640s by Aliocha Maldavsky. A historian at the University of Paris-Nanterre, Maldavsky has mined the Jesuit archive in Rome and manuscript collections in Spain, Peru, and Chile to reconstruct her central story, which is indicated by the title of her book: "Uncertain Vocations, Vocaciones inciertas." This is a provocative and original formulation of her thesis. For the leadership in Rome, there was a strong conviction that mission among unbelievers constituted the major purpose for Jesuits who traveled overseas. Maldavsky demonstrates that as the Spanish, Italian, Belgian, and Portuguese missionaries arrived in the Andes, the ideal of a pure mission was complicated by the Society's entanglements with Spanish colonialism. Herein lies the complexity and subtlety of Maldavsky's analysis. It is best explained by way of an example, drawn from the many poignant and illuminating episodes in her book, all carefully reconstructed from archival sources.

On 21 December, 160o, the Jesuits of Peru met at a provincial congregation in Lima, the colonial capital on the Pacific coast. A debate broke out over the evangelizing of native Americans. On one side stood Nicolas Mastrili Duran, a Neapolitan who entered the Society in 1585 and arrived in 1592 in Peru. Thirtythree years of age in 160o, Duran had yet to take his final vows but was already superior of the Jesuit residence in Juli on the shore of Lake Titicaca in the Andean mountains, an important doctrina de indios (community of native converts). The personnel catalogue of 1601 characterized him as "un gran obrero de indios" [a great worker with Indians]. Speaking passionately on behalf of missions to native Americans, Duran argued that every Jesuit was obliged to learn the indigenous languages. Opposing this statement was Diego Álvarez de Paz, rector of the Jesuit college in Cuzco, the ancient Inca capital in the highlands. A native of Spain, Álvarez entered the Society in 1578 and arrived in Peru in 1585 . He took his final vows in 1594 and was thirty-nine years old in 1601. A professor of theology in Cuzco, Álvarez undertook no missionary activities among the native Americans because he did not speak their languages. While supporting indigenous missions, Álvarez disagreed with Duran's linguistic and missionary imperatives, arguing that the Jesuits in Peru could choose their specialization and not everyone was obliged to learn Quechua or Amara.

Behind this disagreement, news of which reached the Jesuit curia in Rome, lay a fundamental tension in the development of the Jesuit province of Peru, which depended on royal patronage. Jesuits from Europe traveled to Spanish America on board Spanish vessels, their passage and stipends paid for by the 
Spanish crown. In the 1570s, Acosta was keenly aware that the presence of the fathers formed part of Philip II's plan to strengthen royal authority against the unruly encomenderos in the Andes. The new governor, the strong-willed Francisco de Toledo, who governed between 1569 and 1581, expected all royal subjects, the missionaries included, to fall in line. Yet, Spanish policy provoked strong condemnation. In the same year that Toledo was appointed governor, the Spanish Jesuit Luis López questioned the legitimacy of the conquest and described the Spaniards in the following terms: Their principal aim was to acquire and get rich, and to this end they undertook spiritual things, if anyone was up to it at all, which was a most regrettable thing. They were extremely brutal toward the indigenous people, who appeared more animal than human to them; for in treating them this way they could advance their goal, which was to get silver, or thinking about changes to the land in a way that reflected a perpetual desire to advance, to search for new lands, only in order to dominate them, and for silver. ${ }^{2}$ A decade later, the outspoken López was arrested by the governor and shipped back to Spain. There were no more critics of Spanish conquest; the Society made its peace with the colonial order.

In accommodating with Spanish colonialism, the Jesuit enterprise in Peru was acquiring more and more European characteristics: colleges were founded, Latin grammar was expounded, literature and philosophy were taught, as the Jesuits became preceptors to sons of the colonial elites, who began to enter the Society in greater numbers after the first generation of missionary pioneers from Europe. The proportion of "Americanos" (with a handful of exceptions, these were all creoles since mestizos and native Americans were not accepted into the Society) increased from $13.7 \%$ of the seventy-three Jesuits in Peru in 1576 to $38.3 \%$ of the 490 Jesuits in $1637 .^{3}$ Quite a few were sons of encomenderos or other members of the Spanish colonial elites. Many knew indigenous languages; some engaged in native missions; but few were fired up by the idea of evangelizing among native peoples, which was the passion behind so many indipetae letters and the motivation for so many European Jesuit missionaries who went overseas. The Jesuit province in Peru was normalized as a European province, and the question of indigenous missions (along with the imperative of learning indigenous languages), became a matter of controversy.

General Acquaviva supported indigenous missions, but the contradictions remained. As the Spanish colonial state became ever more firmly anchored on the coastal capital of Lima and in the highland city of Cuzco, demands

2 Maldavsky, Vocaciones inciertas, 85 .

3 Ibid., 225. 
increased for the fathers to attend to the spiritual needs of the Spanish population: to preach sermons, to teach Latin, to hear confession, to direct confraternities, and to mediate disputes. Yet the Spanish colonial state continued to expand beyond the watershed of the Andes, past the silver-mining town of Potosi and down its eastern slopes, into Paraguay and the western reaches of the vast Amazon basin, and southward into Chile. In the vanguard of this expanding empire, other Jesuits embarked on missions, often accompanied by Spanish soldiers, to Christianize, to pacify, and to extend the realms of God and king. At times, the missionaries ventured alone into hostile territory, some were martyred; others organized and led native American settlements, the famous reducciones of Paraguay. The sheer geographical extent of this Jesuit enterprise demanded further administrative division. Between 1605 and 1607, the northern part of the viceroyalty of Peru became the new Jesuit province of New Granada, comprising today's Ecuador and Colombia; the southern part split off and became the vice-province of Chile; and the Paraguay mission was conceded to Portuguese Jesuits from Brazil. While necessitated by geography, it is abundantly clear that the split also reflected deep policy disagreements within the Peruvian province. The creation of New Granada and Chile as Jesuit entities gave a strong impetus to new missions among the native populations, while the Jesuits in the truncated Peruvian province did some hard soulsearching about their clerical vocation.

In the 1610s, after the splitting of the Peruvian province, the Jesuits found a renewed sense of vocation in the so-called missions for the extirpation of idolatry. The aim of these missions, as their name suggests, was to root out native religious and cultural traditions that remained in practice even after Christianization. The main targets for these missions were the huacas, mummified ancestral remains, and sacred pre-Christian sites, which still attracted native allegiance. Attributing the inadequacy of native Christianization to the low quality of the parish clergy, and equating the survival of native traditions with potential subversion, the colonial state appointed Jesuit missionaries as experts in these campaigns of repression. The fathers visited the various native parishes and cooperated with the local clergy in rooting out "superstitions." To support this campaign, the governor established a school for the education of sons of caciques, the chieftains, and a prison for the incarceration of offenders. These extirpation-of-idolatry missions differed little in form from the "flying missions" (misiones volantes) undertaken periodically by the Jesuits in Peru throughout the 1570s, 80s, and 9os. Similar to the famous Jesuit preaching missions in rural Spain, Italy, and France, these earlier missions, usually undertaken by a pair of missionaries on short tours of a region, visited Christian Indian villages and aimed at strengthening the Christianization of the native 
population. Unlike the extirpation missions, they lacked a specific punitive role. According to Maldavsky, a dip in the frequency of these flying missions in the 1580 s and gos reflected a decline in missionary fervor, which was renewed in the extirpation campaign as the newly truncated Peruvian province found in it a new outlet for missionary energy and identity.

The insights of Maldavsky's study are not limited to the Peruvian Jesuits; her study represents a model of scholarship in the thoroughness in which she searched the archives and the care with which she interrogated her sources. She reads with a critical eye the cartas anuas, the secret triennial reports (compiled by provincials and containing evaluations of the personnel), and the missionary letters. She reconstructs the different generations and cohorts of Jesuits in the Peruvian province in great detail. The wealth of prosopographical material, lucidly depicted in thirteen graphs and tables, tells us who the Jesuits were (European or American), how they advanced their career, whether they engaged in missions to native Americans, the way they were trained, and their age cohorts, etc. Nine maps help the reader visualize the preaching missions between 1576 and 1611 and understand the administrative division of the Peruvian province. Her critical eye and her sources have shown us that Jesuit records contain a wealth of information not only on the history of the Society and its missions, but also significant data for interpreting the larger political, economic, cultural, and social developments of the societies with which the missionaries were engaged. All in all, Vocaciones inciertas is an excellent and exemplary piece of scholarship.

Behind the "uncertain vocations" of the Peruvian Jesuits a larger historical development was unfolding in all the Spanish colonies. The Catholic mission, unthinkable without European maritime expansion, made far more accommodations to Iberian colonialism than acculturation in indigenous, non-Western cultures. In race, language, and culture, in the use of labor levée and slaves, in the assertion of European superiority in matters of religion, the Catholic church and all missionary orders accommodated with the Iberian colonial regimes. In Spanish America, in Brazil and Portuguese India, the Jesuits accommodated to the racial hierarchy of colonial society, with professed European fathers and some creoles at the top, with creoles, mestizos, and native peoples (in Japan and China) filling the ranks of non-professed fathers and the coadjutores spirituales, and with a mix of Europeans, creoles, and natives forming the coadjutores temporales. In Spanish America and Brazil, Jesuit institutions depended on the latifundia, which used native corvée and African slave labor for economic production. In part, this reflected financial necessity, as promised royal funds were often not forthcoming or in arrears; in part, this exemplified the inherent logic of the missionary enterprise, as 
the Jesuit colleges, residences, and missions functioned in a colonial socioeconomic regime that depended on corvée and slave labor.

The consciences of many missionaries were pricked by the brutality and injustice of the colonial regime. Such was the Jesuit effort on behalf of native Americans in Brazil that the colonists in Salvador da Bahia, with the support of the local city council, rioted against the fathers in $1610 .{ }^{4}$ Everywhere in Brazil, colonists and Jesuits clashed over the question of Indian rights. In the south, conflict focused on the enslavement, first begun in 1611 and intensifying during the 1620 s and 163os, by colonists in São Paulo directed against the Spanish reductions of the Jesuit province of Paraguay. In central Brazil, local authorities and colonists in São Vicente expelled the Jesuits in 1640 for their opposition to Indian enslavement. Colonists in São Paulo followed their example and the Society did not return until 1653 . The problem of slavery was gravest in the north. In Maranhão, established as a vice-province in 1615, the defense of Indian rights found a strong champion in António Vieira (1608-1697). Born in Brazil of Portuguese parents, Vieira was the most important Portuguese Jesuit on either side of the Lusophone Atlantic. In 1652, with the support of General Gottifredi and King João IV, Vieira and other Jesuits tried to free Indians unjustly enslaved in Maranhão but were thwarted by popular violence. Undaunted, Vieira obtained new royal decrees in Lisbon in 1655 against enslavement. The tireless efforts of the Society on behalf of native rights led to three expulsions between 1661 and 1685 . In the face of popular violence and massive colonial interests in Indian enslavement, the Society was also limited by the dispersion of its fifty members in the vast area of northeast Brazil, stretched over a distance of more than 2,00o kilometers. Internally, the Brazil province was torn by tensions between Jesuits of Portuguese and other nationalities, and between those born in Brazil and in Portugal. Even Vieira became a victim of this last struggle. Despite his twenty-six years of service in Brazil, he was deprived of an active voice in governance in 1696, just one year before his death in 1697 in Bahia. The hostility against foreigners reflected Rome's reluctance to admit Brazilian-born Jesuits and the strong role of foreign missionaries in defending native Americans. The most blatant example of disobedience occurred in 1663 when Provincial José da Costa refused to acknowledge the authority of the visitor, the Italian Giacinto De Magistris, an offense for which he was removed from office

4 Charlotte de Castel-L'Etstoile, "The Jesuits and the Political Language of the City: Riot and Procession in Early Seventeenth-Century Salvador da Bahia," in Liam M. Brockey, ed., Portuguese Colonial Cities in the Early Modern World (Farnham: Ashgate, 2008), 41-61. See also her Les ouvriers d'une vigne stérile. Les jésuites et la conversion des Indiens du Brésil, 1580-1620 (Paris: Centre Culturel Calouste Gulbelkian, 200o). 
by General Oliva. The tension between Brazilian and foreign Jesuits culminated in 1700 in the violent expulsion of Italian fathers from the college of Bahia.

\section{Central European Jesuits in Latin America}

The drama in the Jesuit mission was far from over by 1700 . This is made abundantly clear in the series Jesuiten aus Zentraleuropa in Portugiesisch- und Spanisch-Amerika. Ein bio-bibliographisches Handbuch, published under the direction of Johannes Meier, professor in the faculty of Catholic theology at the University of Mainz. Three volumes in this series have been published to date: volume one on Brazil (1618-1760) is written by Meier and Fernando Amado Aymoré, volume two on Chile (1618-1771) by Meier and Michael Müller, and volume three on New Granada (1618-1771) by Meier and Christoph Nebgen. While representing the most systematic effort to compile data on Jesuit missionaries from the German-speaking provinces of Central Europe, this series is not the first effort; in 1899, the Swiss Jesuit Anton Huonder published the first prosopography on this topic. ${ }^{5}$ However, the Mainz project represents much more than an updated prosopography; the published volumes are also important works of interpretation that aim to achieve a balance and dialogue between the history of Jesuit missions and the history of colonial Latin America. A strong intellectual unity is achieved in the three volumes by the adherence to a central scheme. The books begin with a section on the Jesuit province in question, with discussions on sources, topography, economy, and the colonial population. It is followed by a particularly valuable section on the historical ethnology of the indigenous populations that synthesizes the scholarship of anthropologists and linguists. The third section traces the development of the missions to the native populations, giving statistics, maps, and analyzing the activities of the missionaries. The fourth section is devoted to Jesuit missionaries from Central Europe and discusses their recruitment, education, vocation, travel, missionary work, their image of the native American, and their achievements in the sciences, cartography, linguistics, art, mechanics, and the administration of the Society. An indigenous perspective is offered in section five, which necessarily relies on Jesuit sources. The suppression of the Society and the expulsion of Jesuits are dealt with in section six. A summary retrospective is offered in section seven. The eighth and final section is devoted to prosopographical data compiled from the archives, comprising

5 Anton Huonder, Deutsche Jesuitenmissionäre des 17. und 18. Jahrhunderts (Freiburg i. Br, 1899). 
between one-third and two-thirds in length of the entire volumes. Arranged alphabetically under the categories of "priests" and "brothers," the three volumes offer a detailed prosopography of the 161 central-European Jesuits who were missionaries in these three provinces in the colonial period (including those who died en route), with eighty-five in Chile, forty-five in New Granada, and thirty-one in Brazil. The individual entries include the usual biographical data, the curriculum within the Society, transatlantic travel, missionary activities, writings, and existing scholarship.

Why were so many central-European Jesuits eager to embark on missions in colonial Latin America? Readers of Luke Clossey's fine monograph would not be surprised by the global dimension of the Jesuit mission. ${ }^{6}$ What is more, there were two developments that helped to make the eighteenth century the era of the German missionary. The first was politics. Until 1664, Habsburg Spain's jealously excluded all non-Spanish subjects from the colonies. This included missionaries. Of the 130 central-European Jesuits in early modern New Granada and Chile, only three had arrived prior to the lifting of this ban. While a similar restriction did not exist for Portugal's overseas dominions, the seventeenth century was still a slow period for central-European Jesuits in Brazil: only seven of the thirty-one in question arrived prior to 1700 . After 1708, the Portuguese crown turned from tolerance to active sponsorship, thanks to Maria Anna (1683-1760), archduchess of Austria, who married King João V of Portugal in 1708. Greatly attached to the Society, Maria Anna was accompanied by her Austrian Jesuit confessor in Portugal and the queen enthusiastically sponsored missionaries from her native central Europe to the lands under the padroado.

The second development was the Catholic revival in the last decades of the seventeenth century. It took central Europe one generation to recover from the devastations of the Thirty Years War (1618-1648) and only slightly longer for Catholicism to become resurgent in the cultural splendor of the late Baroque and Rococo. New churches went up; pilgrims flocked to shrines; clerical vocations multiplied. The German assistancy, among the five in the Society of Jesus (Spain, Portugal, France, Italy, and Germany) became numerically the strongest in the course of the eighteenth century. Comprising the English, Belgian, German, Bohemian, Austrian, and Polish provinces (Poland and Lithuania were to obtain their own assistancy in the eighteenth century), the German assistancy covered an immense territory. Its growing strength in the eighteenth century was concentrated in the German-speaking provinces of the

6 Salvation and Globalization in the Early Jesuit Missions (Cambridge: Cambridge University Press, 2008). 
Holy Roman Empire and Austrian lands, as the English province and the two Belgian provinces went into a long period of decline. The German assistancy rose steadily in prominence during the seventeenth and early eighteenth centuries as measured by the proportion of Jesuits in these provinces as a percentage of the total number of Jesuits: in 1626 the German assistancy included 5,100 out of 15,544 Jesuits $(32.81 \%)$, and in 1679 the proportion was 6,718 members out of $17,655(38.56 \%)$. This trend of numerical increase continued into the eighteenth century and assumed even more significance when measured against the decline of the Spanish or the stagnancy of the Portuguese assistancy. In the leadership of the Society, Goswin Nickel was the first German to be elected general in 1652 . Under the generalship of a second central European, the Bohemian Franz Retz (1730-50), who was himself frustrated in his quest for an overseas posting, hundreds of central-European Jesuit missionaries threw themselves into the global mission.

When these young men arrived in colonial Latin America, they faced a double culture shock: the tropical Baroque of the Iberians and the "wilderness" of the indigenous. Most moved on as missionaries to the frontiers of the colonial empires: those in Brazil deep into the Amazon basin, beyond the pacified settlements of Christianized native Americans acculturated to Tupi, the indigenous lingua franca; in New Granada, venturing into the dense jungle of the Orinoko to convert nomadic and warlike tribes, a few days' journey but a world apart from the Spanish city of Bogota; in Chile, traveling into the territory of the Araucan south of the River Carampangue, trying to bring the Gospel to indigenous tribes who resisted Spanish domination. Whether conversing in the arcades of Baroque colleges or preaching to native peoples under the dense jungle foliage, whether crossing crocodile infested rivers in the Amazon or hiking on the wind-swept pampas of southern Chile, these Jesuit missionaries from Central Europe, deeply impressed by the novelties and excitement of their adventure, wrote detailed and expressive letters back to family and confreres which were as revealing about their new missions as about themselves. Some decried the sloth of Spaniards, their disdain for manual work and their pretensions for honor, and thereby felt superior about the virtues of the hardworking German Bürger. Others criticized the colonists for their lack of Christian fervor, setting a bad example for the native peoples under their repressive rule: how were the fathers to persuade the tribal peoples to abandon polygyny and adopt monogamy when white Christian men kept concubines? A few were shocked by the lives of the tribal peoples, who seemed less like children of nature than uncivilized beasts; such was the shift in European mentality regarding the native Americans between the voyages of Columbus and the golden age of Iberian colonialism. 
With few exceptions, central-European Jesuits served on indigenous missions. Their presence confirmed the tensions between colonialism and missions in the Jesuit enterprise already manifest in 1600 Peru. The Hispano- and Lusophone Jesuits, increasingly creole in origin, devoted most of their energies to serving their compatriots in the colonial cities of Latin America, while the vast indigenous populations, marginalized by the colonial regimes, were reserved for foreign Jesuits. In Brazil, almost all central Europeans worked in the reductions of the vice-province of Maranhão; similarly, in Chile, they were employed in missions beyond the frontiers of the Spanish colonial state, whether among the warlike Mapuches in Arauco or the more gentle Huilliches on Chiloé Island. To them fell the hardest chores of the Jesuit enterprise. During the colonial period, the Mapuches never completely submitted to Spanish rule and Jesuit establishments were destroyed during their frequent rebellions. It was difficult for the fathers to convince these semi-nomadic tribes to renounce polygyny and warfare, given the behavior of the Spaniards. For Brazil, we have already discussed the repeated clashes between Jesuits and colonists over the enslavement of native Americans. In New Granada, the difficulty exceeded the material hardships of jungle missions. Sailing from the Caribbean, Carib slave-hunters, working for the Dutch and English, landed on the shores of today's Venezuela and Guyana and raided villages on the lower reaches of the Orinoko. In 1684, some 170 Caribs attacked and burned three missionary villages in the Orinoko: they killed or enslaved all Indian converts and murdered the three German Jesuits in charge before mutilating their bodies. These raids continued until the 1730s, forcing the Jesuits to abandon some missions and to call upon Spanish armed protection. A similar story, much better known, was playing out on the Paraguay River in Brazil, but there, at least, the Tupi and their Jesuit missionaries were better equipped to defend themselves.

The problems of conversion were many-nomadism, polygyny, exploitation, and enslavement. There was one solution: reductions. The Spanish term reducción came from the verb reducir, to diminish and cut, that is the consolidation of the large numbers of dispersed indigenous populations, nomadic or settled, into fewer and larger administrative units for easier colonial rule. Since this process involved Christianizing the indigenous populace, the reduction would become the most distinctive feature of the Jesuit mission in colonial America. In 1766, on the eve of the expulsion, there were sixteen centralEuropean Jesuits in charge of sixteen villages and 10,000 souls in the Orinoko; the numbers were much larger in the famous Paraguay reductions. There, as in Maranhão, the Jesuits negotiated with the colonial authorities about the labor obligations of their indigenous flocks, protected them as best as they could 
against predatory colonists, and directed these settlements as benevolent patriarchs to the "child-like" indigenous converts.

Paternalism within the Jesuit missions should be understood in the context of the harsh reality of Iberian colonialism, its most brutal aspect being slavery. The problem confronted the first Jesuits in Brazil. In 1556, Manuel da Nóbrega, one of the first Jesuits in Brazil, wrote to the Portuguese provincial about possible ways to avoid the use of slaves in the Jesuit enterprise. The first Jesuit provincial congregation in Brazil (1568) recognized the obvious: without slave labor, the Jesuit enterprise had no economic foundation. The fathers acknowledged this fact while stipulating that only African slaves, not indigenous peoples, could be employed for unfree labor. Under pressure, General Borja agreed to the provisions. Henceforth, cattle ranching by slaves on Jesuit haciendas formed the economic basis of the Jesuit enterprise in Brazil. In the seventeenth century, the highly profitable sugar and tobacco enterprises were added to the economic regime. Some Jesuits, notably the influential Vieira, vehemently condemned the practices, since they entailed a more demanding and brutal labor regime on the plantations. Nonetheless, a fellow Jesuit, the Italian Giovanni Antonio Andreoni, rector of the Jesuit college in Bahia and provincial of Brazil at the beginning of the eighteenth century, published (albeit under a pseudonym) a work on natural resources, including sugar and tobacco, and their exploitation.

While the German, Austrian, Belgian, and Portuguese Jesuits tried to protect the indigenous converts from enslavement, the task of comforting African slaves was left to a few heroic missionaries. The self sacrifices of Alonso de Sandoval and Pedro Claver, who preached to African slaves in early seventeenth-century Cartagena, the main entrepôt of the African slave trade, are carefully recorded in the annals of Jesuit history. Equally laudable was the German Jesuit Michael Schabel, who arrived in Willemstad in 1705 and preached to the plantation owners, comparing them to Judas: while Jesus' apostle sold him for thirty pieces of silver, the white slave-traders gained ten times more for selling their fellow men. Schabel persuaded two Dutch Catholics in Curaçao to give up slave-trading, a success that demonstrated the efficacy of individual action.

Overall, the Jesuit enterprise was more integrated into the colonial regime by 1760 than in 1600 . Jesuit colleges in Lima and Santiago, elevated to universities, educated many generations of colonial elites, who became strong patrons of the Jesuit enterprise in Peru and Chile. Everywhere in colonial America, the finances of the Society were based on land. In Chile, the richest Jesuit college in Bucalemu owned a vast hacienda: in 1754 the twenty Jesuits directed an establishment of 20,000 cattle, 16,000 sheep, and 12,000 goats, tended by 300 
African slaves. In 1767 , on the eve of their expulsion, the Jesuits owned some 2,000 slaves in Chile.

\section{Jesuit Missions in Asia}

Studies on the economic history of Catholic missions are rare. For, in the poignant words of the seventeenth-century Belgian Jesuit, Ferdinand Verbiest, who encountered an English minister in Gibraltar while traveling to the China mission: they, the Protestants, served Mamon (the Englishman was asking about the Jesuit's stipend), while we, Jesuits, served God. Financial records for the Jesuit missions have not survived well, and most historians of the missions prefer to study the religious and cultural sides of things. For this reason, one welcomes the publication of Lederle's Mission und Ökonomie der Jesuiten in Indien, which is based on a dissertation written at the European University Institute in Florence. The book, however, is not a complete success. Its content does not quite fit the title: only on page 178 (out of 282) does Lederle get to economic networks and missions finances. Altogether, the three chapters on economy and finance constitute only seventy pages in the book. The subtitle does not help. It is unclear what Lederle means by "Intermediäres Handeln" (54-55) other than describing the Jesuits as cultural agents in a general sense. The first hundred pages of the book amount to a listing of topics: the obligatory "state of the field" and sources, historiography on missions, the Jesuits, economic history, transnational history, imperial history, and travel literature. Lederle invokes global history, transnational history, imperial history, theory of "transfer" and "network," and proposes her own "intermediacy approach." What follows is an equally breathless gallop through European perceptions of India from Antiquity to the Renaissance, the Portuguese maritime voyages, their conquests in India, the other Europeans who went there, with separate paragraphs on the Dutch, English, Danes, French, and Germans. A sketch of Catholic and Protestant missions in India follows until we get to the Jesuits in India, the actual topic of the book, on page 116.

Fortunately, the reading becomes more rewarding as the author proceeds to the central topic of her study. The most original and best parts of Mission und Ökonomie are Lederle's discussions of the personnel and finances of the Jesuit Malabar province, based on the analysis of the catalogues of personnel and the account books of the Society. Until the early eighteenth century, the Jesuit enterprise in the Estado da India was heavily Portuguese, with foreign Jesuits (mostly Italian) comprising less than $10 \%$ of the personnel. In Goa, the percentage of Portuguese Jesuits was $91.4 \%$ in 1647 , dropping to $87 \%$ in 
1726; in Malabar, the Portuguese percentage was 93.6\% in 1685, but between 1705 and $175^{2}$ this dropped to an average of $77 \%$. This is an interesting parallel to the developments in Latin America, which showed the divergence between colonial core areas and mission frontiers. In Portuguese India, Goa and its surrounding territory constituted the colonial core, whereas Malabar to the south constituted the frontier, more vulnerable to Dutch attacks and less firmly under colonial control. In the eighteenth century, foreign Jesuits were more likely to be employed in these mission frontiers both in Latin America and in South Asia. The largest groups of non-Portuguese Jesuits in eighteenth-century Malabar were the Germans and Italians: they numbered eight and ten respectively among the sixty-two Jesuits (forty of them Portuguese) there in 1740.

In terms of finances, Lederle reproduces several accounts from the Goa and Malabar provinces. Her figures show a continuing increase in the income of the Goa province between the end of the sixteenth century and 1739. Malabar was less well endowed. While the province's income was still comparable to Goa's in the seventeenth century, it sank to one-quarter of Goa's in 1734 due to losses to the Dutch. By 1740, due to the attacks of the Marathi, the Portuguese lost substantial territory and the Jesuit enterprise suffered a corresponding decline. Coconut and rice provided the bulk of the income, according to Lederle, but her sources do not tell us about the methods of cultivation and the labor regime.

In the eighteenth century, the Catholic mission in Asia had reached its maximum extent and was retreating on different frontiers. China, the cornucopia in dreams of missionary harvests, turned into infertile soil because of the Rites Controversy: in 1705, the Emperor Kangxi forbade his subjects to convert to Christianity; in 1748, the first European Jesuits were martyred; on the eve of the Society's suppression, fewer than seventy Jesuits remained, the majority in the imperial capital Beijing, while others hid from provincial authorities. Taking their cue from China, the rulers in Tonkin and Cochinchina, today's Vietnam, likewise expelled Jesuit missionaries and persecuted Christians. In the missionary fields of South Asia, the Jesuit enterprise faced increasingly active competition from Danish and German Protestants. No Jesuit missionary careers in eighteenth-century Asia were as brilliant as those of Matteo Ricci and Ferdinand Verbiest in China, Roberto de Nobili and Henrique Henriques in India, or Alexandre de Rhodes in Vietnam. Even while Jesuits in Latin America such as Eusebio Kino (1645-1711) was exploring Baja California and expanding the frontiers of Christianity and Spanish rule deep into the north, the missionary space was closed and contracting in Asia.

Was there nostalgia for the age of Ricci, the Italian missionary whose fabled success in Ming China fired the imaginations of early seventeenthcentury Europe? The Jesuit from Macerata was certainly remembered on the 
tercentenary of his death in 1910, when the Catholic mission had been revived in the age of European imperialism. Between that celebration and the 4ooth anniversary of his death, global Christianity has finally repudiated its dependence on European power. The figure of Matteo Ricci has become a symbol of cultural exchange in which peoples of Christian and other faiths are on an equal footing, and of a process of religious conversion based on persuasion rather than coercion. It is apt that UNESCO was the financial sponsor of a conference in the 2010 commemoration, of which La Chine des Ming et de Matteo Ricci is the fruit. It is also felicitous that the organization behind this endeavor came from the Institut Ricci in Paris, whose director, Father Michel Masson, was a former Jesuit missionary in Taiwan and Hong Kong. The editor, Isabelle Landry-Deron, a noted Sinologist at the École des Hautes Études en Sciences Sociales, is best known for her study of the eighteenth-century French Jesuit du Halde, editor of the Lettres édifiantes and author/compiler of the influential work, Description de la Chine, mentioned earlier in this essay.

After the editor's introduction, the thirteen articles in this collection are grouped in three parts. The first, on China and its networks, includes contributions by Michel Cartier on the stature of Ricci in China, Frédéric Wang on the Nanjing literati and Ricci, Li Shenwen on Ricci's two voyages to Beijing, and Viviane Alleton on the knowledge of Chinese transmitted to Europe by Ricci. The second part also comprises four essays, including a short and succinct analysis of the Mongol-Tibetan and central-Asian milieu of late Ming China by the Mongolist Françoise Aubin, an interesting analysis of Ricci's remark on Muslims and Portuguese in Guangzhou by Zvi Ben-Dor Benite, observations of Ricci in contemporary Chinese scholarship by Thierry Meynard, and a careful analysis of the probable extent of Ricci's library in Beijing. Five essays belong to part three, of which four are on the theme of scientific exchange, the fifth being Isaia Iannaccone's contribution on Jesuit voyages. On the theme of science, Jean-Claude Martzloff focuses on the reasons for translating Euclid, while Claudia von Collani, Jean Dhombres, and Pierre Léna discourse more generally on the scientific activities of Ricci and science as a bridge between cultures.

The China of Matteo Ricci was certainly far from the jungles of the Amazon. Indeed, it represented an anti-topos to the missionary fields of the Spanish and Portuguese colonies. For the empire of Great Ming, the Portuguese enclave of Macao was but a wild frontier port, a harbor for the warlike folangi (firanghi) pirates from the Great Western Ocean who eventually submitted to the Ming order. It was a wonder that a few cultivated Western clerics would emerge from this unlikely spot, don the robes of Chinese scholars, master the Chinese language, study the books of that civilization, and speak of a strange yet attractive doctrine of justice, righteousness, and salvation. Ricci's great 
achievement was to remind us that the ideal missionary would profess similarities not distinctions, humanity not exploitation, respect not disdain, even as he explained the unfamiliar doctrines of a strange God to distant peoples.

There was a time when strong feelings divided the scholarly community when it came to Catholic missionaries: some saw them as selfless individuals dedicated to evangelization; others criticized the missionary enterprise as a handmaiden of European colonial expansion and exploitation. A few years ago, after lecturing on the Jesuit mission in seventeenth-century China at a top Chinese university, one student asked me: "Professor, so, were the Jesuits good or bad?" Only recently, in reviewing a study of Matteo Ricci, an eminent historian of China confessed that he felt uncomfortable with the idea that Jesuit missionaries in China might have been the precursors of Sinologists. It is time to move on. The studies reviewed in this essay show us how significant and interesting the study of Catholic missions remains, not only to those historians interested in the history of Christianity, but to all scholars of world history for the precise reason that the missions were launched on a truly global scale thanks to the maritime explorations of Iberia and the rise of western Europe. Missionaries sailed on Portuguese, Spanish, and French ships; they received stipends from Catholic monarchs and popes; they brought with them books, religious objects, art, clocks, watches, scientific equipment, and a worldview that shattered complacencies, inspired understanding, and provoked hostilities.

Instead of looking at Catholic missions in their specific regions, one recent trend has been to examine their global dimensions. The book by Luke Clossey mentioned above, which compares the Jesuit enterprise in colonial Latin America and China, is an example of the scholarship that requires linguistic competence and a truly global perspective. More and more, scholars have become aware of the missionary network linking the Americas with Asia, as the volume edited by Elisabetta Corsi shows. ${ }^{7}$ The work of Meyer and his students, among others, reminds us of the importance of northern European Jesuits who participated in the Catholic enterprise in lands under Spanish and Portuguese rule. European expansion and Catholic missions might be inseparable, but colonialism and evangelization were not inextricably linked. A second trend is the close attention paid to subjects neglected in previous scholarship, namely, the economic and financial history of the missions. How were the missions funded? Who were the patrons in Europe and in the missionary areas? How did the religious orders transfer funds from Europe to China, Japan, and India? Are records in landholding, capital investment, and other forms of financial instrument and accounting available for studying the missions? The work by Lederle points to

7 Elisabetta Corsi, ed., Órdenes religiosas entre América y Asia. Ideas para una historia misionera de los espacios coloniales (Mexico City: El Colegio de México, 2008). 
the importance of this subject, and the recent dissertation by Frederik Vermote on Jesuit finance in the China mission opens up a new vista of research. ${ }^{8}$ It is also important to study the metropolitan area, Europe. Suzanne Lang has explored a small part of the enormous collection of printed books and manuscripts on Catholic missions in European libraries. A desideratum would be to connect the reception of the Catholic missionary press to larger cultural and intellectual trends in Europe in a more analytical and conceptual framework that goes beyond the pioneering work of Donald Lach.

There are still vast territories to explore. Africa remains relatively understudied, with the notable exception of source publications. ${ }^{9}$ There are even fewer studies on Jesuit missions to the Ottoman and Safavid empires. For South Asia, while we have excellent cultural histories of the sixteenth and early seventeenth-century Jesuit mission by Ines G. Županov and Ângela Barreto Xavier, the subsequent period is yet to be explored. ${ }^{10}$ South-east Asia is attracting increasing attention from scholars of Catholic missions, but the considerable body of texts written in chũ nôm by the Vietnamese clergy and converts is still neglected, unlike comparable efforts that have used Chinese and Japanese texts to elucidate the Catholic missions in the early modern period. The greater exploration of historical sources generated by the host societies will surely create a radically new perspective. Africa, Asia, and the Americas will no longer be the frontiers for evangelization, as they had been represented following the itineraries and experiences of European missionaries sailing from the homeland. Instead, the center and the peripheries will reverse. Through indigenous sources, where they exist, we will perceive the image of the stranger coming from afar with their unfamiliar clothes, appearances, and teachings. Without understanding the force of that strange encounter, we would not have the privilege of studying the emotions and reasons behind the conversions, which were the ultimate concern of the missions.

8 "The Role of Urban Real Estate in Jesuit Finances and Networks between Europe and China, 1612-1778" (Ph.D dissertation, University of British Columbia, 2013).

See, for example, Fr. João dos Santos, Etiópia Oriental e Vária História de Cousas Notáveis do Oriente, ed., Maria do Carmo Guerreiro Vieira et al. (Lisbon: Comissão Nacional para as Comemorações Portugueses, 1999) and Michael Boyms Bericht aus Mosambik-1644. Lateinischer Text, Übersetzung und Kommentar, ed., Robert Wallisch (Vienna: Österreichische Akademia der Wissenschaften, 2005).

See Ines G. Županov, Missionary Tropics. The Catholic Frontier in India (16th-17th Centuries) (Ann Arbor: University of Michigan Press, 2005) and Ângela Barreto Xavier, A Invenção de Goa. Poder Imperial e Conversões Culturais nos Séculos XVI e XVII (Lisbon: Imprensa de Ciências Sociais). The situation will be different with the completion of the dissertation by Paolo Aranha at the European University Institute, "Malabar Rites: An Eighteenth-Century Conflict on Social and Cultural Accommodation in the Jesuit Missions of South India." 